\title{
EVALUATION AND PRIORITIZATION OF TOURISM SITES IN KOOHBANAN CITY IN ORDER TO DEVELOP TOURISM IN IRAN
}

\author{
Somayeh Sadat SHAHZEIDI* \\ University of Guilan , Persian Gulf Highway, 5 km - Rd Tehran- Qazvin , Rasht, \\ Guilan Province, Iran, e-mail: shahzeidi2012@yahoo.com, s.shahzeidi@guilan.ac.ir
}

\section{Mohsen POURKHOSRAVANI}

Shahid Bahonar University of Kerman, Department of Geography, Kerman, Kerman Province, Iran, Postcode: 7616913439, e-mail: pourkhosravani@uk.ac.ir

Tayebeh MAHMOUDI MOHAMMAD ABADI

University of Isfahan, Azadi Square, Isfahan, Isfahan Province, Iran, Postcode: 8174673441, e-mail: tayebeh.mahmoodi@gmail.com

\begin{abstract}
Citation: Shahzeidi, S.S., Pourkhosravani, M., \& Mahmoudi Mohammad Abadi T. (2019). EVALUATION AND PRIORITIZATION OF TOURISM SITES IN KOOHBANAN CITY IN ORDER TO DEVELOP TOURISM IN IRAN. GeoJournal of Tourism and Geosites, 25(2), 334348. https://doi.org/10.30892/gtg.25205-363
\end{abstract}

\begin{abstract}
Geographic perspectives make natural and unique attractions and have a high potential for tourism development with regard to spatial and geographical equilibrium. Recreational use of environmental capabilities, in addition to the appropriate facilities and conditions, requires the conservation of natural resources. This feature can be evaluated through the environmental capability measurement of tourism sites and the estimation of tourist demand. So the present research evaluates and prioritizes the tourism sites in Koohban applying VIKOR and TOPSIS Models to develop its tourism. To this aim, after identifying the tourism sites such as watery mills in Daregezk, Gerdukaj, Darehood and Bandar villages, their potentials were evaluated by such indicators as wideness, water resources, distance to tourist attractions, variety of attractions, distance to religious sites, business centers, facilities and services for catering and tourism, other welfare services, environmental diversity and pristineness, scarcity, historical and ancient aspects, apparent beauty and appropriate climates. The results of VIKOR Model imply that the site of Bandar village with point of 0.00189 from VIKOR indicator, point of 0.00376 from satisfaction indicator and point of 0.00153 from dissatisfaction indicator has the first ranking of tourism development in Koohbanan city. Other tourism sites, however, have achieved an acceptable rating in all three VIKOR indicators of satisfaction and dissatisfaction, and according to these indicators, the sites of the mill, Daregezk, Gerdukaj and Darehood ranked second to fifth in tourism development. The obtained results from TOPSIS Model show that Bandar and Daregezk villages with the highest potential and sustainability criteria, with a weight of 0.428 and 0.426 , respectively, are in the first and second priorities,
\end{abstract}

\footnotetext{
* Corresponding author
} 
respectively. The villages of watery mills and Darehood with points of 0.368 and 0.338 have the third and the fourth priorities, respectively. Gerdukaj village with a relatively high point difference and a weight of 0.109 ranks the fifth.

Key words: tourism development, recreational site, Vikor model, Topsis algorithm, Koohbanan

\section{INTRODUCTION}

Nature-oriented tourism is a natural and sustainable tourism which is possible with the participation of indigenous operators and the exploitation of indigenous and natural tourism potentials. In other words, nature tourism is referred to any kind of trip to natural places. In fact, the foundation of this kind of tourism is nature, which is also referred to as naturalist tourism or nature-based tourism. Therefore, paying attention to the importance of its role in protecting the environment in order to achieve sustainable development is essential (Rezvani, 2004:109). In addition to the natural and pristine attractions of each area, geographical space creates such landscapes that, given the spatial conditions and spatial relationships, can have a great potential in the field of tourism. Obviously, the recreation use of the environment both requires the facilities and the appropriate conditions as well as the conservation of these resources. This can be achieved by assessing the environmental capabilities and determining the capacity for receiving resources and estimating tourism demand. It should be noted that different places have potential in various fields, including tourism.

But to use these abilities, we have to turn capability into usability with such an appropriate space; which is a special art that in many cases knowledge of geomorphologists can prepare and discover it. In other words, the understanding and presentation of the relationship between the form and the process has a profound effect on its emotional and aesthetic response, which is geomorphology in the tourism industry (Ramesht et al., 2011: 354). Although many researchers consider the importance of tourism solely in creating incomes and job opportunities, it should be noted that the importance and majesty of the tourism industry is not limited to those cases; in fact, if planned and developed, tourism, and in particular natural tourism, can improve such indicators as social justice, promotion of living standards, public welfare, and regional balance. It should be noted that planning for identifying the characteristics of the destination of tourism causes the region's diversification, tourism growth and vital economic stimuli in each region (Liu et al., 2012: 413).

In general, the main objective of nature tourism is the education and entertainment of tourists from natural phenomena, as well as the protection of the natural environment and its prospects in relation to the lack of change and the avoidance of human intervention in disrupting the face of the earth. In this regard, Pourahmad (2005), while using multi-criteria decision-making models in evaluating tourism capabilities of Semnan province, state that the application of various multi-criteria methods leads to a different ranking of competing alternatives. Therefore, in order to achieve consensus and also more comprehensive ranking of options, the method of integration of the results is proposed as the best method. Mousavi et al., 2005 in an article entitled investigating and prioritizing the power and infrastructure of tourism development in the cities of Kurdistan using a multi-criteria decision making technique reported that in terms of infrastructure indicators of tourism, Sanandaj is highly advanced and Dehgolan and Divandareh districts are at a low level (deprived). Ghanbari et al., 2014 rank the cities of East 
Azarbaijan province based on urban tourism infrastructure with a multi-criteria decision making method. Their results show that Tabriz, Maragheh and Shabestar are the first three cities and Varzaghan, Charavimaq and Khodaafarin are the last three cities of the province based on the availability of urban tourism infrastructures. Mavadat \& Maleki (2014) review the tourism infrastructures in Yazd province using TOPSIS and HDI models and report that tourism infrastructure in Yazd province does not have a good balance. Tyrväinen et al., 2014, while exploring the intentions of tourists in the north of Lapland, Finland, with the aim of environmental preferences and tourist accommodation, emphasize that tourists mainly focus on the relationship of their location with nature, green infrastructure, access and quality of the environment. Doniz-Paez et al., 2011, in another investigative attempt, while studying the geomorphous landscape of volcanoes in Canary islands, Spain conclude that this perspective has scientific, cultural, added value, and use and management values for tourism development. Uysal (2013) in a study titled "Urban Tourism Development" had a comparative comparison of urban tourism in Istanbul and Helenisky and concluded that tourists in both cities were attracted from three points.

Considering the fact that identifying, evaluating and introducing tourist attractions in each region is the first step in the development and planning of regional tourism, as well as the existence of appropriate infrastructure and appropriate distribution of services in attracting tourists to the most prone areas of tourism is very determinative (Taghvaee \& Ranjbar Dastanani, 2010: 23), this research tries to analyze the natural tourism sites of Koohbanan city in accordance with their infrastructure and their tourism characteristics.

\section{THEORETICAL BACKGROUND}

With regard to tourism development, recreational planning and the determination of environmental-human resources is a process that relates people's leisure time to space and environment. This planning is an art and science that uses concepts and methods related to a great deal of scientific orientations to provide public and private recreationaltourism opportunities in and around cities. The main issue in planning and managing tourism development is to create a balance between the power of the natural and social environment with the amount of tourism and recreational activities in a particular region, area or special promenade. This is especially more sensitive in urban sprawl and surrounding areas; as on the one hand, it faces the increase in the demand and limited resources, and on the other hand, there is a risk of increasing environmental problems and issues (Saeidnia \& Mehdizadeh, 2012: 5). In general, successful planning involves essentially five features that are mandatory in the early stages of planning. It is worth noting that the ranking of the following priorities varies among researchers:

A) Estimating and listing all available facilities and facilities that are likely to be used in the future;

B) The assessment of a possible tourist market (origin and nationality of tourists); demand);

C) Examining the areas in which the demand outweighs the supply (channeling

D) Searching to find internal and external financial resources to provide financial aspects of tourism;

E) trying to preserve the natural characteristics, cultural heritage and characteristics of social life (Zaherie, 2012: 97).

Tourism attraction as the main focus of tourism and initial capital of this industry has a very important role in the planning and development of tourism, and therefore, the study of tourist attractions is considered as the basic of tourism industry planning (Heidari Chianeh, 2010: 44-45). Attractions are developed sites designed and managed to 
satisfy the interests and activities of visitors and recreate recreational facilities (Heidari Chianeh, 2017: 59). Since most of Iran's cities and habitats are adjacent to valuable natural resources such as valleys, water areas, bays, springs, etc., recognizing the tourism potential of these natural resources and their relationship with human culture and civilization will have a huge impact on the development of tourism in different regions.

\section{METHODOLOGY}

The present research is based on descriptive and analytical methods based on field visits. At first, while using library studies, through topographical maps, Google Earth images, digital elevation models and field visits, the studied area and the spatial distribution of tourism sites were identified. These sites include water mills, Daregezk, Gerdukaj, Darehood and Bandar villages (Table 1, Figures 1 and 2).

Table 1. Characteristics of the studied tourism sites (Source: Bastani, 2006)

\begin{tabular}{|c|c|c|c|c|}
\hline \multirow{2}{*}{$\begin{array}{l}\text { Tourism } \\
\text { site }\end{array}$} & \multicolumn{2}{|c|}{ Geographical location } & \multirow{2}{*}{$\begin{array}{l}\text { Relative } \\
\text { location }\end{array}$} & \multirow{2}{*}{ Tourism features } \\
\hline & longitude & latitude & & \\
\hline $\begin{array}{l}\text { Asiab } \\
\text { abad } \\
\text { village }\end{array}$ & $56^{\circ} 28^{\prime}$ & $31^{\circ} 18^{\prime}$ & $\begin{array}{l}3 \mathrm{~km} \text { north of } \\
\text { Koohbanan }\end{array}$ & $\begin{array}{l}\text { Villages dating back to the thousand years. the } \\
\text { existence of eight water mills, each of which were } \\
\text { known as a village and has been in operation for } \\
\text { up to 30 years, but now only the eighth mill is effective. }\end{array}$ \\
\hline $\begin{array}{c}\text { Daregezk } \\
\text { village }\end{array}$ & $56^{\circ} 29^{\prime}$ & $31^{\circ} 16^{\prime}$ & $\begin{array}{l}10 \mathrm{~km} \text { north of } \\
\text { Koohbanan }\end{array}$ & $\begin{array}{l}\text { The existence of a natural aquarium, known as } \\
\text { the largest natural aquarium in the south-east of } \\
\text { the country. Many aquatic plants grow in this } \\
\text { aquarium, and there are some fish with the age } \\
\text { of about twenty years. }\end{array}$ \\
\hline $\begin{array}{c}\text { Gerdukaj } \\
\text { village }\end{array}$ & $56^{\circ} 15^{\prime}$ & $31^{\circ} 31^{\prime}$ & $\begin{array}{l}45 \mathrm{~km} \text { north of } \\
\text { Koohbanan }\end{array}$ & $\begin{array}{l}\text { This village is one of the city's summer } \\
\text { residences, where Mount Davadan, with a height } \\
\text { of } 3660 \text { meters, is the highest point in the } \\
\text { Kohhbanan mountains. There are also Gerdukaj } \\
\text { trees in the village, from which the name of the } \\
\text { village is taken, old and thick trees that date back } \\
\text { more than a thousand years. }\end{array}$ \\
\hline $\begin{array}{c}\text { Darehood } \\
\text { village }\end{array}$ & $56^{\circ} 25^{\prime}$ & $31^{\circ} 1^{\prime}$ & $\begin{array}{c}10 \mathrm{~km} \text { north } \\
\text { of Koohbanan }\end{array}$ & $\begin{array}{l}\text { There are mineral water springs coming from } \\
\text { Mount Davadan. There is also a protected area in } \\
\text { the village called Asia. }\end{array}$ \\
\hline $\begin{array}{l}\text { Village of } \\
\text { Bandar }\end{array}$ & $56^{\circ} 24^{\prime}$ & $31^{\circ} 23^{\prime}$ & $\begin{array}{l}10 \mathrm{~km} \\
\text { southeast of } \\
\text { Koohbanan }\end{array}$ & $\begin{array}{l}\text { The presence of natural springs, old trees and } \\
\text { ancient aqueducts, as well as medicinal plants } \\
\text { such as black cumin, Thymus and Artemisia in } \\
\text { the mountain range ( } 2732 \mathrm{~m} \text { high), are the } \\
\text { attractions of the village of Bandar. }\end{array}$ \\
\hline
\end{tabular}

In the next stage, the evaluation indicators were selected according to the purpose of the research as well as previous studies, then the weight of the indicators was determined by the experts. The most important evaluation indicators are shown in Table 2, which are different according to the type of evaluation model. Finally, VIKOR and Technique for Order Preference by Similarity to Ideal Solution (TOPSIS) models were used to prioritize tourism sites. VIKOR is one of the multi-criteria decision-making methods derived from Visekriterijumska Optimizacija IKompromisno which means multi-criteria optimization and compromise solution. The main purpose of this method is to approach the most ideal solution based on compromise and consensus solutions. So that the final answer (Q) is based on compromise and agreement with one or two conditions. This method can help decision makers to make a final decision (Opricovic \& Tzeng, 2004: 447). 

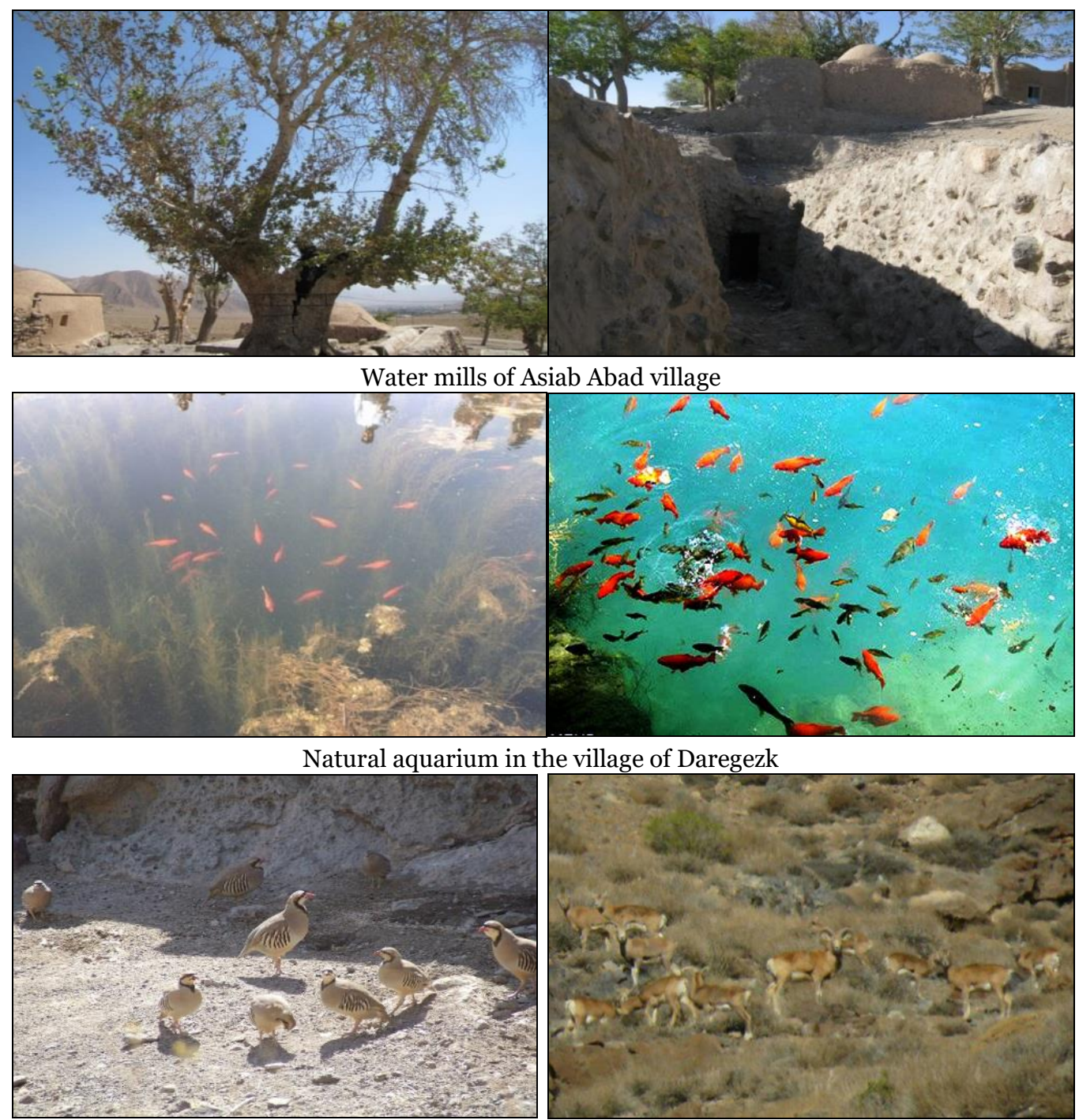

Asia Protected Area in Darehood Village
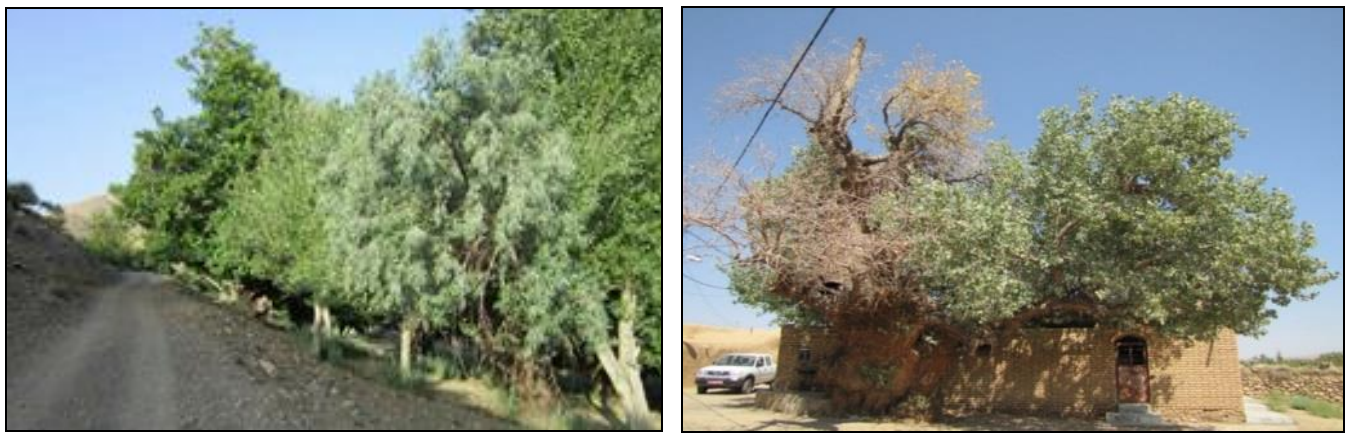

Scenes of the Bandar village

Figure 1. Photographs of studied tourist sites that have portrayed part of tourism attractions 
VIKOR is one of the multi-criteria decision-making methods for solving a discrete decision-making problem with inappropriate criteria and various contradictory measurement units that are presented by Opricovic and Tzeng, 2004.

This method defines a ranked set of available options for conflicting indices so that the ranking of options is based on this goal. This compromise response introduces a multi-criteria ranking index based on the proximity to the ideal answer (Opricovic, 1998: 16). The main purpose of the VIKOR method is to be closer to the ideal answer of each indicator (Pourahmad \& Khaliji, 2014: 12).

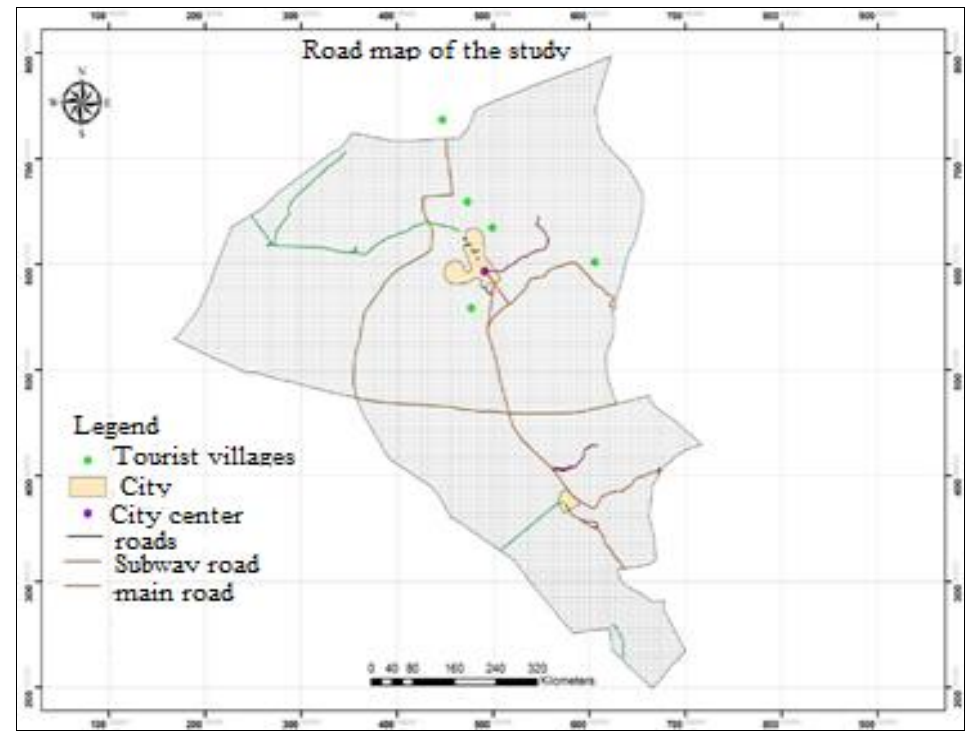

Figure 2. Communication status of the studied sites ( Koohbanan City in Kerman,Iran)

Table 2. Indicators used in each model to evaluate tourism sites (Source: Opricovic \& Tzeng, 2004)

\begin{tabular}{|c|l|l|}
\hline Evaluation model & \multicolumn{1}{|c|}{ VIKOR } & \multicolumn{1}{c|}{ TOPSIS } \\
\hline & Area & Tourist attractions and distance to them \\
& access water sources & $\begin{array}{l}\text { Environmental diversity and } \\
\text { pristineness }\end{array}$ \\
Evaluation & The distance between the mosques and & Scarcity \\
Criteria & the tourist attractions & Historical and ancient \\
& Commercial use & Apparent beauty \\
& Catering and tourism facilities & Good climate \\
& Other services & \\
\hline
\end{tabular}

TOPSIS is one of the ranking techniques based on the similarity to the ideal solution, which was originally developed by Huang and Yoon in 1981. This method has a lower sensitivity than the weighting method of criteria (Malchovsky, 1999: 107), which, due to the compensation, allows the exchange between the indicators; i.e. the weakness of an index may be offset by another index score. In multi-index methods, including TOPSIS, the goal is ranking and selecting the best option (Kohansal, 2009: 93). In this method, option $\mathrm{M}$ is evaluated by the $\mathrm{N}$ index. The principle logic of this model defines the ideal solution (positive) and the ideal negative solution. In this method, in addition to considering the distance of an option from an ideal point, its distance from the ideal point is also considered negatively (Asgharpur, 2009: 263). It means that it has suitable 
options and has a higher priority, which has a minimum distance from the ideal solution and the farthest distance from the ideal negative solution.

In other words, the distance between options is calculated from the positive and negative ideal solution, and then the options are ranked based on the fact that they have the least ideal distance from the positive ideal and the maximum distance from the negative ideal (Deng, 2000: 967). The basis of this method is selecting the option that has the least distance from the positive ideal and the maximum distance from the ideal negative. In this method, the indicator called "The relative closeness of the $\mathrm{i}$-th option to the ideal solution is introduced, and the option with the highest one is chosen".In this method, an indicator titled "The relative closeness of the i-th option to the ideal solution $\left(C_{i}^{+} \operatorname{orC}_{i}^{-}\right)$is introduced, and the option with the highest $C_{i}^{+}$is chosen" (Desheng, 2006). This model is used in order to select a decision-making strategy among several possible solutions according to the desired indicators.

\section{The studied area}

Koohbanan city with an average height of 1945 meters above sea level is located in the northwest of Kerman province and in the position of 56 degrees and 17 minutes in longitude and 31 degrees and 25 minutes in latitude (Figure 3). Interconnected Mountains with a northwest to southeast trend have surrounded this city. Mount Davadan with the height of 3660 meters is the highest point of Koohbanan. The city is bounded from the north to the city of Bafgh, from the south to the city of Zarand, and from the east to the city of Ravar and Behabad, and from the west to Nogh Rafsanjan and Zarand. The protected area of Asyab Mountain, Babaebodan Tower, Takht Amir, old towers and castles, natural aquarium in Dargask village, Sheikh Abu Zayed monastery and eight mills are one of the most important tourist attractions in the city of Kohbanan.

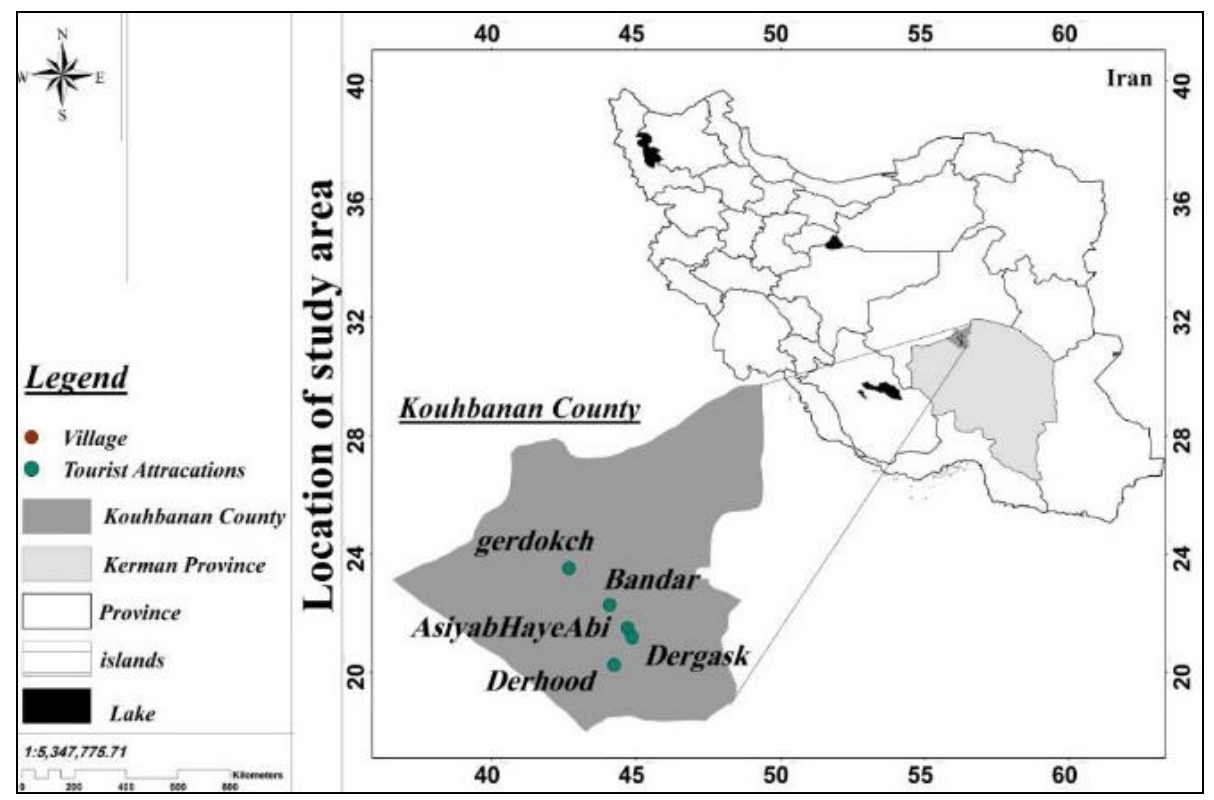

Figure 3. The Geographical location of the studied Discussions and Findings (Tourism Sites in Koohbanan City in Kerman, Iran)

The increasing urbanization and leisure-time geography approach in recent decades have attracted the attention of many countries in considering the tourism industry as the 
largest and most diverse industry and as an achievable goal in the process of sustainable development. Many countries recognize this dynamic industry as the main source of income, job creation, private sector growth, and cultural and human exchange and the development of infrastructure (Tayebi, 2007: 21). Iran, like many parts of the world, is rich in natural attractions and natural potentials along with historical and cultural phenomena. Therefore, the present study has been developed according to the necessity of tourism villages in the city of Koohbanan to study, investigate, identify and introduce as a tourist attraction area. A comparative evaluation of these villages for the development of sustainable tourism has been done applying two frameworks of VIKOR and TOPSIS. Therefore, the results of this study are presented in two separate sections as follows.

\section{Prioritizing tourism sites based on the VIKOR model}

The first step in prioritization in VIKOR model is the formation of a primary matrix which consists of evaluation options and indicators. This matrix has five options of the villages of Asyab Abad, Daregezk, Gerdukaj, Darehood and Bandar, and nine indicators of area, distance to tourist attractions, access, volume of water resources, tourist attractions, mosque distance to tourist attractions, commercial use, facilities for catering and tourism, and other services and has an order of 45 that shows the numerical values of indices in each village (Table 3), which represents the initial matrix of the VIKOR model.

Table 3. Primary VIKOR matrix based on the options and digital values of indicators in eachvillage

\begin{tabular}{|l|c|c|c|c|c|c|c|c|c|}
\hline Indicator/ & Area & $\begin{array}{c}\text { Distance } \\
\text { to tourist } \\
\text { attractions }\end{array}$ & Access & $\begin{array}{c}\text { Volume of } \\
\text { water } \\
\text { resources }\end{array}$ & $\begin{array}{c}\text { Tourist } \\
\text { attractions }\end{array}$ & $\begin{array}{c}\text { Mosque } \\
\text { distance } \\
\text { to tourist } \\
\text { attractions }\end{array}$ & $\begin{array}{c}\text { Commer } \\
\text {-cial use }\end{array}$ & $\begin{array}{c}\text { Facilities } \\
\text { for catering } \\
\text { and tourism }\end{array}$ & $\begin{array}{c}\text { Others } \\
\text { services }\end{array}$ \\
\hline Asyab & 120 & 220 & 9 & 165000 & 1004.1 & 25 & 42 & 21 & 33 \\
\hline Dargask & 150 & 200 & 96 & 145000 & 302.23 & 20 & 39 & 11 & 28 \\
\hline Gordukch & 110 & 300 & 81 & 140000 & 102.71 & 50 & 93 & 32 & 50 \\
\hline Darehud & 140 & 130 & 41 & 137000 & 114.155 & 20 & 54 & 37 & 35 \\
\hline Bandar & 130 & 150 & 61 & 166000 & 102.825 & 30 & 59 & 32 & 35 \\
\hline
\end{tabular}

In the second stage of the VIKOR model, as the unit of the selected indices is different, their units should be deleted before entering into the model, and the quantitative values of each index should be converted into dimensionless one, which can be done through normalization methods. The results of the normalization of the data matrix will be in the format of normalized or dimensionless matrix, which are reported in Table 4.

Table 4. Normalized Matrix of VIKOR Model

\begin{tabular}{|l|c|c|c|c|c|c|c|c|c|}
\hline $\begin{array}{c}\text { Indicator } \\
\text { Site }\end{array}$ & Area & $\begin{array}{c}\text { Distance } \\
\text { to tourist } \\
\text { attractions }\end{array}$ & Access & $\begin{array}{c}\text { Volume of } \\
\text { water } \\
\text { resources }\end{array}$ & $\begin{array}{c}\text { Tourist } \\
\text { attractions }\end{array}$ & $\begin{array}{c}\text { Mosque } \\
\text { distance } \\
\text { to tourist } \\
\text { attractions }\end{array}$ & $\begin{array}{c}\text { Commer } \\
\text {-cial use }\end{array}$ & $\begin{array}{c}\text { Facilities } \\
\text { for catering } \\
\text { and tourism }\end{array}$ & $\begin{array}{c}\text { Others } \\
\text { services }\end{array}$ \\
\hline Asyab & 0.18 & 0.22 & 0.03 & 0.22 & 0.62 & 0.17 & 0.15 & 0.16 & 0.18 \\
\hline Dargask & 0.23 & 0.20 & 0.33 & 0.19 & 0.19 & 0.14 & 0.14 & 0.08 & 0.15 \\
\hline Gordukch & 0.17 & 0.30 & 0.28 & 0.19 & 0.06 & 0.34 & 0.32 & 0.24 & 0.28 \\
\hline Darehud & 0.22 & 0.13 & 0.14 & 0.18 & 0.07 & 0.14 & 0.19 & 0.28 & 0.19 \\
\hline Bandar & 0.20 & 0.15 & 0.21 & 0.22 & 0.07 & 0.21 & 0.21 & 0.24 & 0.19 \\
\hline
\end{tabular}

The third step in the VIKOR model is to weigh the indicators and prioritize them. Since the indices have different priorities in option selection stage, this step is done through various weighting methods such as network analysis, hierarchical 
analysis, entropy, and so on. In this study, entropy weighting method was used to prioritize the indices. In this method, the more variables of a single index are distributed, the more important it is. The results are presented in Table 5, in which water resources with the volume of 0.995 has gained the largest volume. In the fourth step, with a similar multiplication of the weight of indices in the normalized matrix, the normal matrix is obtained, which is provided in Table 6.

Table 5. Weighting indexes and prioritizing them based on entropy model

\begin{tabular}{|l|c|c|c|c|c|c|c|c|c|}
\hline Indicator & Area & $\begin{array}{c}\text { Distance } \\
\text { to tourist } \\
\text { attractions }\end{array}$ & Access & $\begin{array}{c}\text { Volume of } \\
\text { water } \\
\text { resources }\end{array}$ & $\begin{array}{c}\text { Tourist } \\
\text { attractions }\end{array}$ & $\begin{array}{c}\text { Mosque } \\
\text { distance } \\
\text { to tourist } \\
\text { attractions }\end{array}$ & $\begin{array}{c}\text { Commer } \\
\text {-cial use }\end{array}$ & $\begin{array}{c}\text { Facilities } \\
\text { for catering } \\
\text { and tourism }\end{array}$ & $\begin{array}{c}\text { Others } \\
\text { services }\end{array}$ \\
\hline E & 647.60 & 973.00 & 257.24 & 751415.39 & 1157.79 & 138.99 & 277.67 & 127.18 & 178.80 \\
\hline $\begin{array}{l}\text { Standard } \\
\text { Deviation }\end{array}$ & -646.60 & -972.00 & -24.256 & -751414.39 & -1156.79 & -137.99 & -276.67 & -126.18 & -177.80 \\
\hline Weight & 0.0009 & 0.0013 & 0.0003 & 0.9950 & 0.0015 & 0.0002 & 0.0004 & 0.0002 & 0.0002 \\
\hline
\end{tabular}

Table 6. The weighted normal matrix in VIKOR model

\begin{tabular}{|c|c|c|c|c|c|c|c|c|c|}
\hline $\begin{array}{c}\text { Indicatof } \\
\text { Site }\end{array}$ & Area & $\begin{array}{c}\text { Distance } \\
\text { to tourist } \\
\text { attractions }\end{array}$ & Access & $\begin{array}{c}\text { Volume of } \\
\text { water } \\
\text { resources }\end{array}$ & $\begin{array}{c}\text { Tourist } \\
\text { attractions }\end{array}$ & $\begin{array}{c}\text { Mosque } \\
\text { distance } \\
\text { to tourist } \\
\text { attractions }\end{array}$ & $\begin{array}{l}\text { Commer } \\
\text {-cial use }\end{array}$ & $\begin{array}{c}\text { Facilities } \\
\text { for catering } \\
\text { and tourism }\end{array}$ & $\begin{array}{c}\text { Others } \\
\text { services }\end{array}$ \\
\hline Asyab & 0.00016 & 0.00028 & 0.00001 & 0.21804 & 0.00095 & 0.00003 & 0.00005 & 0.00003 & 0.00004 \\
\hline Dargask & 0.00020 & 0.00026 & 0.00011 & 0.19161 & 0.00028 & 0.00003 & 0.00005 & 0.00001 & 0.00004 \\
\hline Gordukch & 0.00014 & 0.00039 & 0.00010 & 0.18500 & 0.00010 & 0.00006 & 0.00012 & 0.00004 & 0.00007 \\
\hline Darehud & 0.00018 & 0.00017 & 0.00005 & 0.18104 & 0.00011 & 0.00003 & 0.00007 & 0.00005 & 0.00005 \\
\hline Bandar & 0.00017 & 0.00019 & 0.00007 & 0.21936 & 0.00010 & 0.00004 & 0.00008 & 0.00004 & 0.00005 \\
\hline
\end{tabular}

Table 7. The values of the lowest and the highest normal matrices and their anomalies

\begin{tabular}{|c|c|c|c|c|c|c|c|c|c|}
\hline Indicator & Area & $\begin{array}{c}\text { Distance } \\
\text { to tourist } \\
\text { attractions }\end{array}$ & Access & $\begin{array}{c}\text { Volume of } \\
\text { water } \\
\text { resources }\end{array}$ & $\begin{array}{c}\text { Tourist } \\
\text { attractions }\end{array}$ & $\begin{array}{c}\text { Mosque } \\
\text { distance } \\
\text { to tourist } \\
\text { attractions }\end{array}$ & $\begin{array}{c}\text { Commer } \\
\text {-cial use }\end{array}$ & $\begin{array}{c}\text { Facilities } \\
\text { for catering } \\
\text { and tourism }\end{array}$ & $\begin{array}{c}\text { Others } \\
\text { services }\end{array}$ \\
\hline Maximump.00020 & 0.00039 & 0.00011 & 0.21936 & 0.00095 & 0.00006 & 0.00012 & 0.00005 & 0.00007 \\
\hline Minimum & 0.00014 & 0.00017 & 0.00001 & 0.18104 & 0.00010 & 0.00003 & 0.00005 & 0.00001 & 0.00004 \\
\hline $\begin{array}{l}\text { Deducing } \\
\text { min from } \\
\text { max }\end{array}$ & 0.00005 & 0.00022 & 0.00010 & 0.03832 & 0.00085 & 0.00004 & 0.00007 & 0.00003 & 0.00003 \\
\hline
\end{tabular}

Table 8. Values of Satisfaction Indicators (S) and Dissatisfaction (R) in VIKOR model

\begin{tabular}{|c|c|c|c|c|c|c|c|c|c|c|c|}
\hline Indicatof & Area & $\begin{array}{c}\text { Distance } \\
\text { to } \\
\text { tourist } \\
\text { attracti } \\
\text {-ons }\end{array}$ & Access & $\begin{array}{c}\text { Volume } \\
\text { of } \\
\text { water } \\
\text { resour } \\
\text {-ces }\end{array}$ & $\begin{array}{c}\text { Tourist } \\
\text { attracti } \\
\text {-ons }\end{array}$ & $\begin{array}{c}\text { Mosque } \\
\text { distance } \\
\text { to tourist } \\
\text { attracti } \\
\text {-ons }\end{array}$ & $\begin{array}{c}\text { Commer } \\
\text {-cial use }\end{array}$ & $\begin{array}{c}\text { Facilities } \\
\text { for } \\
\text { catering } \\
\text { and } \\
\text { tourism }\end{array}$ & $\begin{array}{c}\text { Others } \\
\text { services }\end{array}$ & $\begin{array}{c}\text { Satis } \\
\text { faction }\end{array}$ & $\begin{array}{c}\text { Dissatis } \\
\text {-faction }\end{array}$ \\
\hline Asyab & 0.00064 & 0.0006 & 0.00034 & 0.034 & 0 & 0.00015 & 0.0003 & 0.00010 & 0.00018 & 0.036 & 0.034 \\
\hline Dargask & 0 & 0.0007 & 0 & 0.720 & 0.0011 & 0.00018 & 0.0003 & 0.00017 & 0.00024 & 0.723 & 0.720 \\
\hline Gordukch & 0.0008 & 0 & 0.00006 & 0.892 & 0.0015 & 0 & 0 & 0.00003 & 0 & 0.894 & 0.892 \\
\hline Darehud & 0.0002 & 0.0012 & 0.00021 & 0.995 & 0.0015 & 0.00018 & 0.0002 & 0 & 0.00016 & 0.998 & 0.995 \\
\hline Bandar & 0.0004 & 0.0011 & 0.00014 & 0 & 0.00153 & 0.00012 & 0.00023 & 0.00003 & 0.00016 & 0.003 & 0.001 \\
\hline
\end{tabular}


The fifth step of the VIKOR model is the determination of the minimum and maximum numerical values of each index in the normal matrix and their anomalies, i.e., the fraction of the minimum item from the maximum, the results of which are reported in Table 7. In the sixth step of the VIKOR model, the satisfaction index (S) and dissatisfaction index (R) are calculated. In this method, the maximum number of normal weight matrices in each index is deducted from the normal weight matrix elements in the same index and is divided into the maximum and minimum anomalies, the results of which are given in Table 8.

In the seventh step of the VIKOR model, the final ranking of the options is performed; at this stage, the VIKOR value (Q) is calculated using equation (1) and is accepted with two conditions, so that the lower the $Q$ value, the higher this option has priority if it has at least one of the following two conditions:

A: The difference between the second and the first option is greater than or equals to DQ. The DQ is calculated from (2), where $\mathrm{n}$ is the number of options. Accordingly, given the lower Q2-Q1 difference from the DQ value, the first condition is not acceptable.

$\mathrm{B}$ : The first option must always maintain its rank in $\mathrm{S}$ or $\mathrm{R}$ in addition to the $\mathrm{Q}$. As you can see, not only the first option (the village of the port), but all the options in all three indices (R, S, Q) have maintained their ranks. Therefore, the second condition is accepted (Atashin \& Sasani, 2013:107).

Equation 1: $\mathrm{Q}=\mathrm{V} \times\left[\frac{\mathrm{S}_{\mathrm{i}}-\mathrm{S}^{*}}{\mathrm{~S}^{-}-\mathrm{S}^{*}}\right]+(1-\mathrm{V}) \times\left[\frac{\mathrm{S}_{\mathrm{i}}-\mathrm{S}^{*}}{\mathrm{~S}^{-}-\mathrm{S}^{*}}\right]$

Equation 2:

$\mathrm{DQ}=1 /(\mathrm{n}-1) \rightarrow \frac{1}{5-1}=0.25$

$\mathrm{Q} 2-\mathrm{Q} 1=(0.0330-0.00189)=0.0311$

In these relationships, $\mathrm{Q}=$ the VIKOR index, $\mathrm{V}=$ the fixed number which equals to 0.5, $\mathrm{S}^{-}=\mathrm{MaxSi} R^{*} \cdot S^{*}=\mathrm{MinSi}$, MinSi $\mathrm{R}^{-}=\mathrm{MaxSi}$.

The results of the final ranking of options based on the VIKOR model are shown in Table 9 and Figure 4. As we can see, the villages of Bandar and Asiababad are the first priorities of tourism development with VIKOR values of 0.00189 and 0.03303 , respectively.

Table 9. Final ranking of Tourism Sites in Koohbanan City based on the VIKOR model

\begin{tabular}{|l|c|c|c|c|c|c|}
\hline Site & $\begin{array}{c}\text { VIKOR } \\
\text { value }\end{array}$ & $\begin{array}{c}\text { Final } \\
\text { VIKOR rank }\end{array}$ & $\begin{array}{c}\text { Satisfaction } \\
\text { index }\end{array}$ & $\begin{array}{c}\text { Final } \\
\text { satisfaction rank }\end{array}$ & $\begin{array}{c}\text { Dissatisfaction } \\
\text { index }\end{array}$ & $\begin{array}{c}\text { Final } \\
\text { dissatisfaction } \\
\text { index }\end{array}$ \\
\hline Bandar & 0.00189 & 1 & 0.00376 & 1 & 0.00153 & 1 \\
\hline Asyab & 0.03303 & 2 & 0.03667 & 2 & 0.03431 & 2 \\
\hline Daregezk & 0.22536 & 3 & 0.72344 & 3 & 0.72056 & 3 \\
\hline Gerdukaj & 0.89769 & 4 & 0.89459 & 4 & 0.89212 & 4 \\
\hline Darehood & 1.00189 & 5 & 0.99888 & 5 & 0.99506 & 5 \\
\hline
\end{tabular}

The problem solving process according to the TOPSIS model consists of several steps, the first step of which is to determine the indices for the formation of the data matrix. In this research, data matrices include options of water mills, Daregezk, Gerdukaj, Darehood and Bandar villages and indicators including environmental diversity and pristineness, scarcity, historical and ancient aspects, apparent beauty and proper climate. In this section, only the quantitative and numerical values of the indicators are reported for the formation of data matrices, the results of which are presented in Table 10. This matrix consists of five options and five indicators, whose rows and columns form a 25 -fold matrix. 


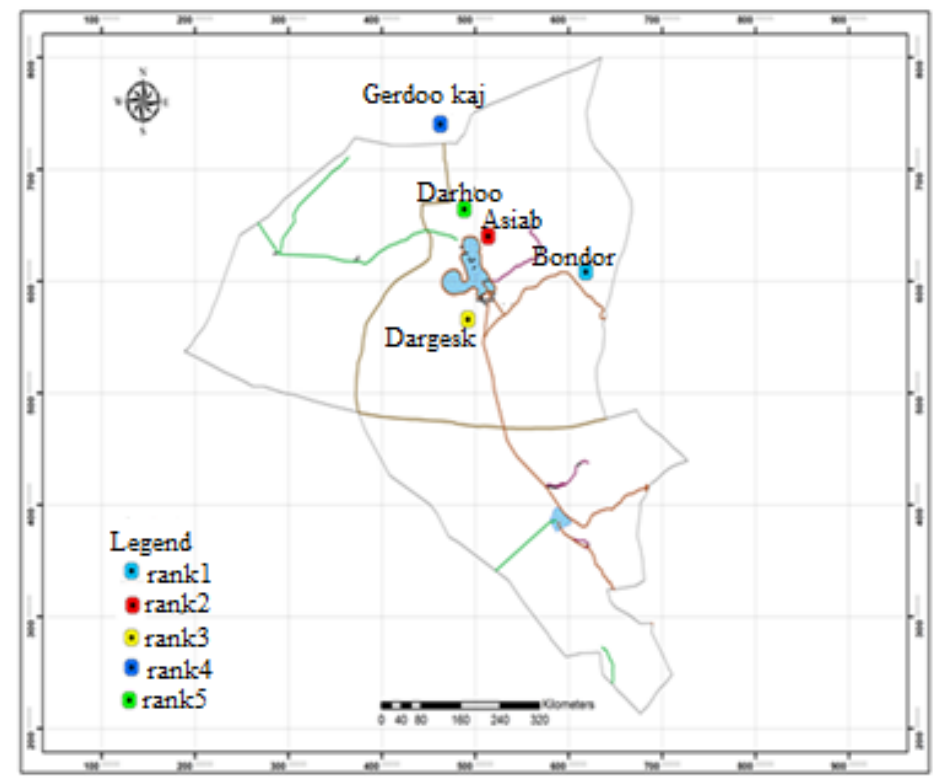

Figure 4. The final ranking of Tourism Sites in Koohbanan City based on the VIKOR model Prioritizing Tourism Sites Based on TOPSIS Algorithm

Table 10. Decision-making matrix and quantitative values of indices in TOPSIS algorithm

\begin{tabular}{|l|c|c|c|c|c|}
\hline $\begin{array}{c}\text { Indicators } \\
\text { Options }\end{array}$ & $\begin{array}{c}\text { Environmental diversity } \\
\text { and pristineness }\end{array}$ & Scarcity & $\begin{array}{c}\text { Historical and } \\
\text { ancient aspects }\end{array}$ & $\begin{array}{c}\text { Apparent } \\
\text { beauty }\end{array}$ & $\begin{array}{c}\text { Appropriate } \\
\text { climate }\end{array}$ \\
\hline Water mills & 0.575 & 0.61 & 0.6 & 0.525 & 0.26 \\
\hline Daregezk & 0.73 & 0.6 & 0.63 & 0.5 & 0.59 \\
\hline Gerdukaj & 0.26 & 0.44 & 0.475 & 0.45 & 0.53 \\
\hline Darehood & 0.575 & 0.49 & 0.30 & 0.58 & 0.51 \\
\hline Bandar & 0.375 & 0.31 & 0.40 & 0.45 & 0.6 \\
\hline
\end{tabular}

Since the selected indices have multiple units, so matching, inserting and measuring them is not allowed in the model in the same way. As a result, their unit should be deleted and the quantitative values of each index should be converted to the model dimonsionlessly. The results of the non-dimensionalization of the data matrix will be normalized or non-dimensional matrices, which are reported in Table 11.

Table 11. Dimensionless or normalized matrix in TOPSIS algorithm

\begin{tabular}{|l|c|c|c|c|c|}
\hline $\begin{array}{l}\text { Indicators } \\
\text { Options }\end{array}$ & $\begin{array}{c}\text { Environmental diversity } \\
\text { and pristineness }\end{array}$ & Scarcity & $\begin{array}{c}\text { Historical and } \\
\text { ancient aspects }\end{array}$ & $\begin{array}{c}\text { Apparent } \\
\text { beauty }\end{array}$ & $\begin{array}{c}\text { Appropriate } \\
\text { climate }\end{array}$ \\
\hline Water mills & 0.486 & 0.543 & 0.541 & 0.476 & 0.226 \\
\hline Daregezk & 0.617 & 0.534 & 0.568 & 0.444 & 0.514 \\
\hline Gerdukaj & 0.219 & 0.392 & 0.428 & 0.400 & 0.462 \\
\hline Darehood & 0.486 & 0.436 & 0.270 & 0.516 & 0.445 \\
\hline Bandar & 0.317 & 0.276 & 0.360 & 0.400 & 0.523 \\
\hline
\end{tabular}

Since the effects of indicators on the prioritization of alternatives are not the same and different from each other, the indices must first be compared to each other in a pairwise comparison, and their importance are entered introduced into the computational process of 
the algorithm in the form of quantitative values in the vector of weight. Therefore, in order to prioritize the indices and compare them with each other in a pairwise fashion, the Shannon entropy model was used, the results of which were reported in Table 12. As can be seen, the environmental diversity and apparent beauty indices have the highest and lowest priorities, respectively, with the values of 0.352 and 0.0006 respectively.

Table 12. Weight vector resulting from paired comparison of indices in Shannon entropy model

\begin{tabular}{|l|c|c|c|c|c|c|c|c|}
\hline Indicators & $\begin{array}{c}\text { Environmental } \\
\text { diversity and } \\
\text { pristineness }\end{array}$ & Scarcity & $\begin{array}{c}\text { Historical } \\
\text { and ancient } \\
\text { aspects }\end{array}$ & $\begin{array}{c}\text { Apparent } \\
\text { beauty }\end{array}$ & $\begin{array}{c}\text { Appropriate } \\
\text { climate }\end{array}$ & $\begin{array}{c}\text { Confidence } \\
\text { value }\end{array}$ & $\mathrm{dj}$ & $\begin{array}{c}\text { Weight } \\
\text { vector }\end{array}$ \\
\hline $\begin{array}{l}\text { Environmental } \\
\text { diversity and } \\
\text { pristineness }\end{array}$ & 0.228 & 0.248 & 0.249 & 0.209 & 0.104 & .9610 & 0.039 & 0.352 \\
\hline Scarcity & 0.290 & 0.244 & 0.261 & 0.199 & .2360 & 0.979 & 0.021 & 0.189 \\
\hline $\begin{array}{l}\text { Historical and } \\
\text { ancient aspects }\end{array}$ & 0.103 & 0.179 & 0.197 & 0.179 & .2120 & 0.976 & 0.024 & 0.216 \\
\hline Apparent beauty & 0.228 & 0.2 & 0.124 & 0.231 & 0.204 & 0.993 & 0.0007 & 0.0006 \\
\hline $\begin{array}{l}\text { Appropriate } \\
\text { climate }\end{array}$ & 0.149 & 0.126 & 0.166 & 0.179 & 0.240 & 0.974 & 0.026 & 0.234 \\
\hline
\end{tabular}

In order to prioritize the indices in the computational process of the algorithm, their weight vector is multiplied equally well in the dimensionless matrix. The results are equal to the formation of a dimensionless matrix that is reported in Table 13. The ideal situation indicates the desirability. Therefore, considering the positive and negative effects of the indicators in prioritizing options, the minimum and maximum values indicate the desirable situation and represents the ideals. That is, if the parameter has a negative effect, the minimum value of it represents the ideal is positive and vice versa. According to the above principle, the ideals of the study indicators are reported in Table 14.

Table 13. Non-scale weighted matrix in the TOPSIS algorithm

\begin{tabular}{|l|c|c|c|c|c|}
\hline $\begin{array}{c}\text { Indicators } \\
\text { Options }\end{array}$ & $\begin{array}{c}\text { Environmental diversity } \\
\text { and pristineness }\end{array}$ & Scarcity & $\begin{array}{c}\text { Historical and } \\
\text { ancient aspects }\end{array}$ & $\begin{array}{c}\text { Apparent } \\
\text { beauty }\end{array}$ & $\begin{array}{c}\text { Appropriate } \\
\text { climate }\end{array}$ \\
\hline Water mills & 0.080 & 0.046 & 0.053 & 0.0012 & 0.024 \\
\hline Daregazk & 0.102 & 0.046 & 0.056 & 0.0011 & 0.055 \\
\hline Gerdukaj & 0.036 & 0.033 & 0.042 & 0.0010 & 0.049 \\
\hline Darehood & 0.080 & 0.037 & 0.026 & 0.0013 & 0.047 \\
\hline Bandar & 0.052 & 0.023 & 0.035 & 0.0010 & 0.056 \\
\hline
\end{tabular}

Table 14. Positive and Negative Ideal Matrices in the TOPSIS Algorithm

\begin{tabular}{|l|c|c|c|c|c|}
\hline $\begin{array}{c}\text { Indicators } \\
\text { Ideals }\end{array}$ & $\begin{array}{c}\text { Environmental diversity } \\
\text { and pristineness }\end{array}$ & Scarcity & $\begin{array}{c}\text { Historical and } \\
\text { ancient aspects }\end{array}$ & $\begin{array}{c}\text { Apparent } \\
\text { beauty }\end{array}$ & $\begin{array}{c}\text { Appropriate } \\
\text { climate }\end{array}$ \\
\hline Ideal solution & 0.125 & 0.070 & 0.243 & 0.080 & 0.044 \\
\hline Non-ideal solution & 0.073 & 0.052 & 0.03 & 0.041 & 0.033 \\
\hline
\end{tabular}

In terms of the effect of prioritizing the regions, the most desirable option will be the option which has the least relative distance to the positive ideal and the maximum relative distance to the negative ideal. From the relative relationship between the distances to the positive and negative ideals, the relative weight of the options is calculated, which is reported in Table 15. Relative weight values usually vary between 
zero and one, the highest weight referring to the highest priority, and the lowest weight indicates the lowest priority. According to its values, the ranking of the options was performed according to Table 15 and Figures 5 to 8.

Table 15. Ideal solution matrix and prioritization of options in TOPSIS algorithm

\begin{tabular}{|c|c|c|}
\hline Options & Weight & Rank \\
\hline Water mills & 0.368 & Third \\
\hline Daregezk & 0.426 & Second \\
\hline Gerdukaj & 0.109 & Fifth \\
\hline Darehood & 0.338 & Fourth \\
\hline Bandar & 0.428 & First \\
\hline
\end{tabular}

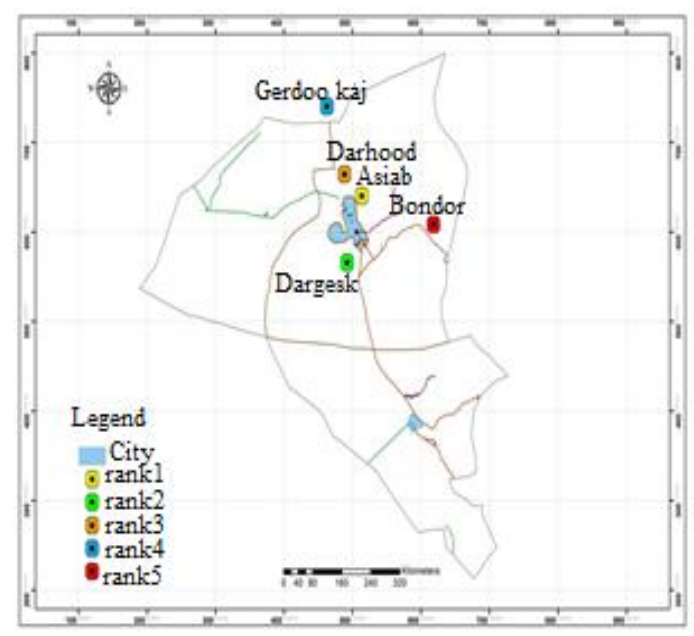

Figure 6. Prioritization of options based on the dimensionless matrix

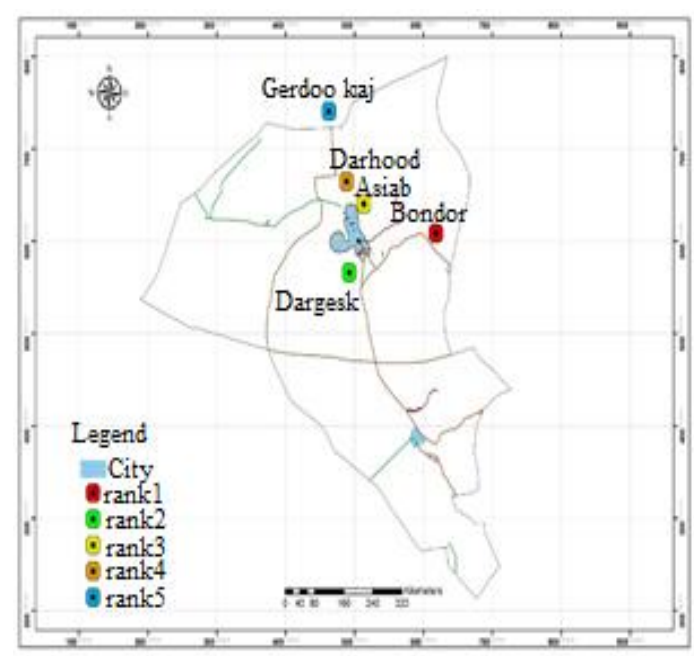

Figure 8. Final prioritization of the options based on the TOPSIS model

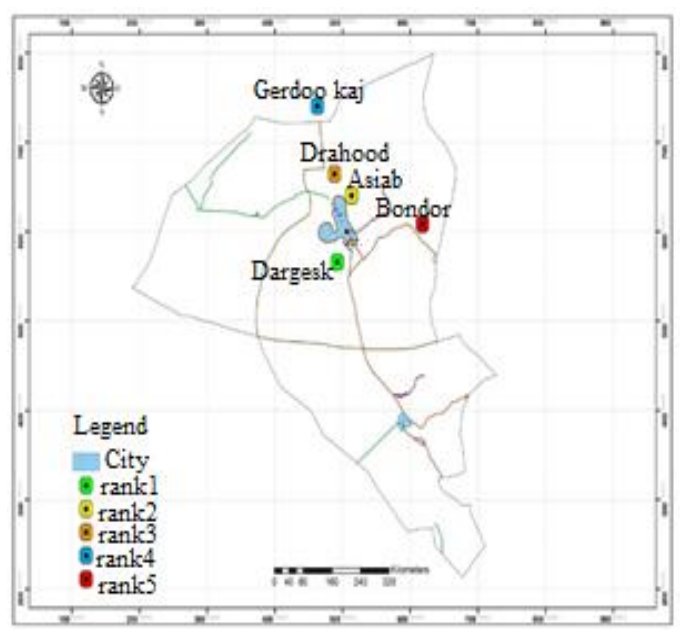

Figure 5. Prioritization of options based on the data matrix

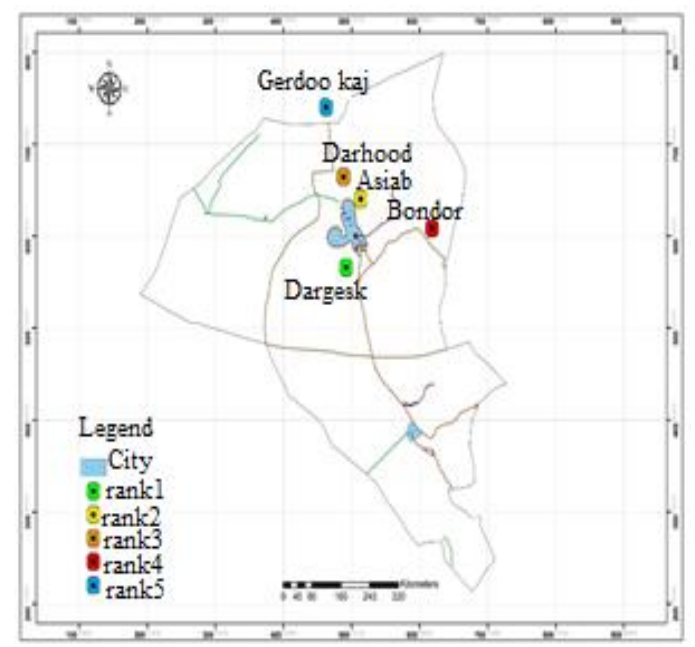

Figure 7 . Prioritization of options based on the weighteddimensionless matrix 


\section{CONCLUSION}

Today, the tourism industry has functions with a comprehensive dimension in all economic, social and cultural spheres, and it is a very suitable platform for any country, taking into account its capacity and ability. But the expansion of the tourism industry in every part of the world requires special conditions such as climate, historical and cultural influences, natural attractions, customs and traditions, infrastructures, facilities and equipment (Hosseini et al., 2013: 2) and most importantly, identifying and introducing tourism potentials in different regionsIn the meantime, natural tourism will have a unique ability to attract tourists and boost the tourism industry due to the diversity of shapes and attractions. In this regard, this research has investigated the potential of natural tourism sites in Koohbanan city for tourism development using the VIKOR's technique. To prioritize attractions, based on the VIKOR's model, the indicators of area, distance, accessibility, water resources, tourism features, distance to religious, commercial, service sites, and other required infrastructures are used.

As stated above, according to the VIKOR model, the site that ranked first in the development of tourism should, in addition to $\mathrm{Q}$ in $\mathrm{S}$ or $\mathrm{R}$, always maintain its rank.

According to the results of Table 4, the Tourism Site of Bandar with a score of 0.00189 from the VIKOR Index (Q), the score of 0.00376 from the Satisfaction Index (S) and the score of 0.00153 from the Dissatisfaction Index (R) ranked the first for development Tourism in Koohbanan city. It should be noted that according to the results of the research, not only the first option (Bandar site), but all the options have maintained their ranks in all three indices $(R, S, Q)$. So that according to these indicators, the sites of Asyab, Daregezk, Gardokuch and Darehood ranked second to fifth for tourism development in this city.

The results of the TOPSIS model show that the villages of Bandar and Daregazk have the highest potential and sustainable tourism criteria with a weight of 0.428 and 0.426 respectively in the first and second priorities of tourism development. The villages of water mills and Darehood with a score of 0.368 and 0.338 , have the third and fourth priorities, respectively. The village of Ghodrokhay has been ranked fifth with a weight of 0.109.

\section{REFERENCES}

Atashin, Panjeh, S., \& Sasani, A. (2013). Applying logarithmic fuzzy preference programming and vikor methods for supplier selection: A case study. Journal of American Science, vol9, P.105 -109.

Asgarpour,M.J. (2009). Multiple Criteria Decision Making. Tehran University Publication.

Bastani Parizi, M.E., \& Beygom-Rouholallahamini, F. (2006). Local History of Kohbanan. Sokhan Gostar Publishing.

Doniz- Paez , J., Ramirez ,R., Cardenas, E., Martin, C., \& Lahoz, E. (2011). Geomorphosites and geotourism in volcanic landscape: the example of La Corona Del lajial cinder cone (El hierro, Canary Islands, Spain). Geo Journal of Tourism and Geosites, 8: P.185-197.

Desheng, Wu, \& Olson, D.L. ( 2006). A TOPSIS Data Mining Demonstration and Application to Credit Scoring. International Journal of Data Warehousing \& Mining, 2(3), July-September ,p:1- 10

Deng, H., Yeh, C.-H., \& Willis, R.J. (2000). Inter-company comparison using modified TOPSIS with objective weight. Computers \& Operations Research, 27, 963-973.

Ghanbari, A., Shojaei Vand , Bahman., \& Zinely, B. ( 2014). Geography and Urban Planning - Regional, Ranking of East Azarbaijan Province Cities Based on Urban Tourism Infrastructure with MultiCriteria Decision Making Methods Volume 4, Issue 12; 89-111.

Heidari Chaineh, R.. (2007). Evaluation of Urban Tourist Attractions by Conditional Valuation Method a Case Study of Shorabil Gravity. Ardabil, Urban Tourism Journal, Vol. 4, No. 1, p. 57-70.

Heidari Chianeh, R. (2010). The Basics of Tourism Industry Planning. Tehran, Samt Publication.

Hosseini, A., Poor Ahmad, A., Orooji, H., \& Alizadeh, M. (2013). Priority of Measuring Development Strategies for Cultural Tourism in Alamut, Qazvin. Journal of Human Geography Research, Volume 45, Issue 3, P. 1-17. 
Kohansal, M.R., \& Rafiei, H. (2008). Selection and ranking of sprinkler and traditional irrigation systems in Khorasan Razavi province. Journal of Agricultural Industries, Special Economics and Agricultural Development, Vol. 22, No. 1, p: 68-84.

Liu,C ., Tzeng, G., \& Lee, M. (2012). Improving tourism policy implementation. In the use of hybrid MCDM models, Tourism Management, 33, p. 413-426.

Mavadat, E., \& Maleki, S. (2014). An analysis of the Distribution and Prioritization of Tourism Infrastructures in Yazd Province Using Programming Techniques. Journal of Applied Geographical Sciences, Vol. 14, No. 34, p. 47-68.

Mousavi, M., Veisian, M., Mohammadi- Hamidi,S., \& Akbari, M. (2005). Investigating and Prioritizing the Power and Infrastructure of Tourism Development with Multi-Criteria Decision Making (a Case Study of Kurdistan Province). Urban Tourism Magazine, Volume 2, Issue 1, P.17-31.

Malczewski, J. (1999). GIS and Multicriteria Decision Analysis, John Wiley \& Sons, New York.

Zaherie, M. (2012). Planning in the Tourism Industry. Geography and Planning Journal. No. 10, 16, p:93-108.

Opricovic, S. (1998). Multi-criteria Optimization of Civil Engineering Systems. Faculty of Civil Engineering, Belgrade.

Opricovic, S., \& Tzeng, G. (2004). Compromise solution by MCDM methods: A comparative analysis of VIKOR and TOPSIS. European Journal of Operational Research, Vol, 156, Issue 2, p. 445-455.

Poor Ahmad, A., \& Khaliji, MA. (2004). Utility Analysis of Urban Services Using the VIKOR Technique (A Case Study of Bonab City). Journal of Spatial Planning, Volume 4, Issue 2, P. 1-16.

PoorAhmad, A., Shahbazpour, A., \& Khaliji, M.A. (2005). Using Multivariate Decision-Making Models in Assessing Tourism Capabilities (A Case Study of Semnan Province). Journal of Geographical Studies in Arid Areas, Year 6, Number 21, p. 50-66.

Ramesht, M.H., \& Shahzidi, S.S. (2011). The application of geomorphology in national, regional and tourism planning, Isfahan, Samt Publication.

Rezvani, M.R., \& Safaei, J. (2005). Tourism of the second house and its effects on rural areas: Opportunity or threat (the Case ofRural areas of northern Tehran). Journal of Geographical Research, No. 54,p. 109-121.

Saeednia, A., \& Mahdizadeh, J. (2012). Urban Tourism, Municipal Green Book. thirteenth volume, Tehran, Publications of the Organization of Municipalities and Dignitaries of the country.

Taghvaei, M., \& Ranjbar Dastanaei, M. (2010). An Analysis of Distribution of Facilities and Services for the Northeast of Chaharmahal va Bakhtiari Province. The journal of Urban Research and Planning, Vol. 1, No. 1,p. 21-48.

Tyrväinen, L., Uusitalo, M., Silvennoinen, H., \& Hasu, E. (2014). Towards sustainable growth in naturebased tourism destinations: Clients' views of land use options in Finnish Lapland. Landscape and Urban Planning, Volume 122, 1-15.

Tayebi, S.K. (2007). Investigating the Relationship between Tourism Development and Economic Growth in Iran (1383-1383). Journal of Humanities and Social Sciences, No. 1, 2008, Issue 22 , p: 68-84.

Uysal, Ü.E. (2013). Urban Tourism Promotion: What Makes the Difference. Journal of Social Sciences, Volume 5, Issue 1,p. 17-27.

Submitted:

30.10.2018
Revised:

09.04.2019
Accepted and published online 12.04.2019 